\title{
Polyfluorenes Without Monoalkylfluorene Defects
}

Sung Yong Cho, ${ }^{\dagger, *}$ Andrew C. Grimsdale, ${ }^{\ddagger}$ David J. Jones, ${ }^{*}$ Scott E. Watkins ${ }^{\ddagger}$ and Andrew B. Holmes $*+\frac{+}{t}, \S$

Contribution from Melville Laboratory for Polymer Synthesis, Department of Chemistry, University of Cambridge, Lensfield Road, Cambridge CB2 1EW, United Kingdom, School of Chemistry, Bio21 Institute, University of Melbourne, Victoria 3010, Australia, and Department of Chemistry, Imperial College, South Kensington, London, SW7 2AZ, United Kingdom.

E-mail: aholmes@unimelb.edu.au

Keywords: conjugated polymers, alkylated fluorene, defect-free, green emission, electroluminescence.

${ }^{\dagger}$ Melville Laboratory for Polymer Synthesis, University of Cambridge.

* School of Chemistry, Bio21 Institute, University of Melbourne.

${ }^{\S}$ Department of Chemistry, Imperial College. 


\section{Summary of the relevant literature}

Reviews of light-emitting polymers. ${ }^{1-6}$

A number of approaches have been adopted to achieve stable blue emission from polyfluorenes including copolymerisation with anthracene, ${ }^{7}$ attachment of aryl groups in place of alkyl substituents, ${ }^{8-10}$ blending with triarylamines, ${ }^{11}$ and treatment of the monomers with base to attempt to remove any monoalkylated material. ${ }^{12}$ Attachment of dendrimers,${ }^{13}$ introduction of twisted biphenyls, ${ }^{14,15}$ use of triarylamine end groups, ${ }^{16}$ or electron-deficient end groups ${ }^{17}$ and incorporation of adamantanes ${ }^{18}$ have also been employed with success. Extensive studies of model materials carrying a fluorenone unit have supported the case for this unit being responsible for the long wavelength emission in polyfluorenes. ${ }^{19-22}$

\section{General methods}

${ }^{13} \mathrm{C}\left\{{ }^{1} \mathrm{H}\right\}$ NMR spectra were recorded on Varian Inova 500 or Varian Inova 400 instruments using $\mathrm{CDCl}_{3}$ as an internal deuterium lock. IR spectra were recorded on a Perkin Elmer Spectrum One FT-IR Spectrometer. UV-Vis spectra were recorded using a Cary Bio 8G spectrometer. Photoluminescence spectra were recorded on Varian Cary Eclipse Fluorescence Spectrometer. Thin films were prepared from toluene solution (15 
Polyfluorenes Without Monoalkylfluorene Defects. Supporting Information. ( ja074634i)

$\mathrm{mg} / \mathrm{mL}$ ) on cut microscope slides with a Cammax Precima spin-coater at $2000 \mathrm{rpm}$ for 1 min. Melting points were determined using Bïchi 510 melting point apparatus, and are uncorrected. Accurate mass spectra were recorded at CSIRO Molecular and Health Technologies on a ThermoQuest MAT95 high resolution mass spectrometer, employing $70 \mathrm{eV}$ electron energy. Gel Permeation Chromatography measurements were performed at CSIRO Molecular and Health Technologies using a Waters 717plus autosampler, Waters 515 HPLC pump and a Waters 2414 refractive index detector. A $100 \mu \mathrm{L}$ injection was used and samples were passed through three $30 \mathrm{~cm}$, PL gel $(5 \mu \mathrm{m})$ mixed C columns and one $30 \mathrm{~cm}$, PL gel $(3 \mu \mathrm{m})$ mixed E column at $1 \mathrm{~cm}^{3} \mathrm{~min}^{-1}$ with THF as solvent. Molar masses are calculated relative to polystyrene standards. Thermogravimetric analysis was carried out on a Perkin Elmer Pyris 1 Thermogravimetric Analyzer. Differential scanning calorimetric measurements were measured on a Perkin Elmer Sappire Differential Scanning Calorimeter. Column chromatography was carried out on silica gel [Merck Kieselgel 60 (230-430 mesh)]. TLC was performed on $0.25 \mathrm{~nm}$ thick plates precoated with Merck Kieselgel $60 \mathrm{~F}_{254}$ silica gel, and visualized by UV light (254 and $366 \mathrm{~nm}$ ) or by developing with an aqueous cerium(VI) solution. Reagents and solvents were used as obtained from commercial suppliers except where indicated otherwise. 


\section{2-Carbomethoxybiphenyl (1)}

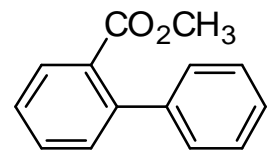

A mixture of biphenyl-2-carboxylic acid (10 g, $50.5 \mathrm{mmol})$, conc. sulphuric acid (50 mg, $0.5 \mathrm{mmol})$ and methanol $\left(200 \mathrm{~cm}^{3}\right)$ was heated at reflux for 20 hours. The solvent was evaporated under reduced pressure to give a crude oil. The residue was dissolved in petroleum ether $40-60{ }^{\circ} \mathrm{C}$ and filtered. The organic phase was extracted with aqueous sodium bicarbonate solution $\left(10 \% ; 3 \times 30 \mathrm{~cm}^{3}\right)$, and water $\left(3 \times 30 \mathrm{~cm}^{3}\right)$ and then dried over magnesium sulphate and evaporated under reduced pressure. The crude was distilled using Kugelrohr distillation apparatus $\left(100 \mathrm{mmHg}, 100-110{ }^{\circ} \mathrm{C}\right)$ to give the title compound as colourless liquid (6.3 g, $59 \%)$.

${ }^{1} \mathrm{H}$ NMR (500 MHz; $\left.\mathrm{CDCl}_{3}\right) \delta 3.65(3 \mathrm{H}, \mathrm{s}), 7.34-7.44(7 \mathrm{H}, \mathrm{m}), 7.54(1 \mathrm{H}, \mathrm{dd}, J=8,8)$, $7.85(1 \mathrm{H}, \mathrm{d}, J=8) ;{ }^{13} \mathrm{C} \mathrm{NMR}\left(125 \mathrm{MHz}, \mathrm{CDCl}_{3}\right) \delta 51.9,127.0,127.1,127.9,128.2$, $129.7,130.6,130.8,131.2,141.2,142.4,169.1$; The $\delta_{\mathrm{H}}$ and $\delta_{\mathrm{C}}$ data are in agreement with the literature values. ${ }^{23}$ 


\section{2-Iodobiphenyl ${ }^{24}(3)$}

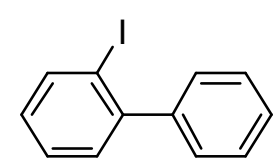

2-Aminobiphenyl (10 g, $59.1 \mathrm{mmol})$ was added slowly to a stirred mixture of conc.

hydrochloric acid $\left(35.4 \% ; 27 \mathrm{~cm}^{3}, 76.8 \mathrm{mmol}\right)$ and water $\left(100 \mathrm{~cm}^{3}\right)$. Aqueous sodium nitrite solution $(20 \% ; 22.4 \mathrm{~g}, 65 \mathrm{mmol})$ was added to the mixture below $5{ }^{\circ} \mathrm{C}$ for $20 \mathrm{~min}$ and stirred for $1 \mathrm{~h}$ at the same temperature. The mixture was added to an aqueous solution of KI (11.9 g, $118.2 \mathrm{mmol})$ in water $\left(100 \mathrm{~cm}^{3}\right)$ slowly and stirred overnight at room temperature. Diethyl ether $\left(100 \mathrm{~cm}^{3}\right)$ was added to the mixture and the organic phase was separated. The aqueous phase was extracted with diethyl ether $\left(3 \times 100 \mathrm{~cm}^{3}\right)$. The combined organic phases were dried over magnesium sulphate. The solvent was evaporated under reduced pressure and purified by column chromatography (petroleum ether $40-60{ }^{\circ} \mathrm{C}$ only). The crude product was dissolved in dichloromethane $\left(100 \mathrm{~cm}^{3}\right)$ and treated with aqueous sodium hydroxide $\left(33 \% ; 50 \mathrm{~cm}^{3}\right)$ to decolorize. The organic layer was isolated and dried over magnesium sulphate. The resultant solution was evaporated under reduced pressure and purified by column chromatography (petroleum ether $40-60{ }^{\circ} \mathrm{C}$ only) to give the title compound as colourless liquid (14.5 g, $\left.88 \%\right)$. 
Polyfluorenes Without Monoalkylfluorene Defects. Supporting Information. ( ja074634i)

${ }^{1} \mathrm{H}$ NMR $\left(500 \mathrm{MHz} ; \mathrm{CDCl}_{3}\right) \delta 7.06(1 \mathrm{H}, \mathrm{ddd}, J=8,8,2), 7.32-7.43(3 \mathrm{H}, \mathrm{m}), 7.41-$

7.47 (4H, m), $7.98(1 \mathrm{H}, \mathrm{dd}, J=8,2) ;{ }^{13} \mathrm{C} \mathrm{NMR}\left(125 \mathrm{MHz}, \mathrm{CDCl}_{3}\right) \delta$ 98.6, 127.6, 127.9,

$128.1,128.7,129.2,130.0,139.4,144.1,146.5$. The $\delta_{\mathrm{H}}$ and $\delta_{\mathrm{C}}$ data are in agreement with the literature values. ${ }^{24}$

\section{9-Heptadecanone ${ }^{25}$ (4)}

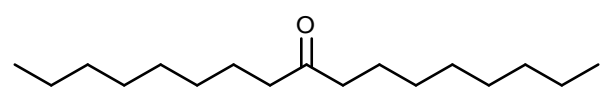

To a suspension of $\mathrm{AlCl}_{3}(4 \mathrm{~g}, 30.0 \mathrm{mmol})$ in dichloromethane $\left(35 \mathrm{~cm}^{3}\right)$ was added nonanoic chloride $\left(5.4 \mathrm{~cm}^{3}, 30 \mathrm{mmol}\right)$ at $-78{ }^{\circ} \mathrm{C}$ over 10 min under nitrogen. The mixture was allowed to warm up to room temperature and stirred for $1 \mathrm{~h}$. The mixture was cooled down to $-78{ }^{\circ} \mathrm{C}$ before trioctyl aluminium (25\% in hexane; $26.4 \mathrm{~cm}^{3}, 12.1$ mmol) was added. The mixture was allowed to warm up to room temperature and stirred overnight before being quenched with water $\left(30 \mathrm{~cm}^{3}\right)$. The organic phase was separated and the aqueous phase extracted with diethyl ether $\left(2 \times 20 \mathrm{~cm}^{3}\right)$. The combined organic phases were washed with aqueous sodium bicarbonate solution $(15 \%, 3 \times 30$ $\left.\mathrm{cm}^{3}\right)$ and water $\left(2 \times 30 \mathrm{~cm}^{3}\right)$ before being dried over magnesium sulphate. After removal of the solvent under reduced pressure, the residue was purified by column 
Polyfluorenes Without Monoalkylfluorene Defects. Supporting Information. ( ja074634i)

chromatography (dichloromethane:petroleum ether $40-60{ }^{\circ} \mathrm{C}=1: 4$ ) on silica gel and recrystallised from ethanol to give the title compound as white solid (5.1 g, $67 \%)$.

m.p. $50{ }^{\circ} \mathrm{C}$ (lit. $\left.{ }^{26} 50{ }^{\circ} \mathrm{C}\right) ;{ }^{1} \mathrm{H}$ NMR $\left(500 \mathrm{MHz} ; \mathrm{CDCl}_{3}\right) \delta 0.86(6 \mathrm{H}, \mathrm{t}, J=7) 1.24-1.27$ $(20 \mathrm{H}, \mathrm{m}), 1.52-1.55(4 \mathrm{H}, \mathrm{m}), 2.36(4 \mathrm{H}, \mathrm{t}, J=7) ;{ }^{13} \mathrm{C} \mathrm{NMR}\left(125 \mathrm{MHz} ; \mathrm{CDCl}_{3}\right) \delta 14.1$, $22.6,23.8,29.1,29.2,29.4,31.8,42.8,211.8$. The $\delta_{\mathrm{H}}$ and $\delta_{\mathrm{C}}$ data are in agreement with the literature values. ${ }^{26}$

\section{9-Biphen-2-yl-heptadecan-9-ol (2a)}

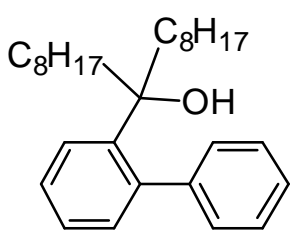

(Route 1, Scheme 1)

1-Bromooctane $\left(14.5 \mathrm{~cm}^{3}, 82.9 \mathrm{mmol}\right)$ was added slowly to a mixture of magnesium $(3.0 \mathrm{~g}, 0.12 \mathrm{~mol})$ and dry diethyl ether $\left(50 \mathrm{~cm}^{3}\right)$ for $30 \mathrm{~min}$ to keep the mixture at a gentle reflux. The mixture was then stirred for $2 \mathrm{~h}$ at room temperature. 2Carbomethoxybiphenyl 1 (4.0 g, $18.9 \mathrm{mmol})$ was dissolved in a separate flask in dry diethyl ether $\left(50 \mathrm{~cm}^{3}\right)$ and the resultant Grignard reagent was transferred via syringe to 
the mixture at $0{ }^{\circ} \mathrm{C}$. The mixture was stirred overnight at room temperature before being quenched with aqueous ammonium chloride solution $\left(10 \% ; 5 \mathrm{~cm}^{3}\right)$ and water $\left(10 \mathrm{~cm}^{3}\right)$ at $0{ }^{\circ} \mathrm{C}$. The organic phase was separated and the aqueous phase was extracted with ether $\left(2 \times 20 \mathrm{~cm}^{3}\right)$. The combined organic phases were dried over magnesium sulphate before being evaporated under reduced pressure to give the crude oil. The crude oil was purified by column chromatography (petroleum ether $40-60{ }^{\circ} \mathrm{C}$ : dichloromethane $=7: 3$ ) on silica gel to give the title compound as a colourless oil (2.8 g, $36 \%)$.

Anal. Calcd. for $\mathrm{C}_{29} \mathrm{H}_{44} \mathrm{O}$ : C, 85.2; H, 10.9. Found: C, 85.3; H, 11.0. IR (neat liquid) $3479,2955,2923,2856,1466,1443,1377,1072,1009,915,758,704 \mathrm{~cm}^{-1} ;{ }^{1} \mathrm{H}$ NMR $\left(500 \mathrm{MHz} ; \mathrm{CDCl}_{3}\right) \delta 0.90(6 \mathrm{H}, \mathrm{t}, J=7) 1.01-1.34(24 \mathrm{H}, \mathrm{m}), 1.54-1.60(2 \mathrm{H}, \mathrm{m}) 1.62(1$ H, br s), 1.68-1.74 (2 H, m), $7.06(1 \mathrm{H}, \mathrm{dd}, J=8,1) 7.22-7.28(3 \mathrm{H}, \mathrm{m}), 7.35-7.40(4 \mathrm{H}$, m), $7.58(1 \mathrm{H}, \mathrm{dd}, J=8,1) ;{ }^{13} \mathrm{C} \mathrm{NMR}\left(125 \mathrm{MHz} ; \mathrm{CDCl}_{3}\right) \delta$ 14.1, 22.6, 23.7, 29.3, 29.5, $29.9,31.8,43.2,78.8,125.5,126.9,127.1,127.1,127.5,129.0,131.9,139.9,143.1$, 143.9; MS (EI) m/z (rel intensity) 407.3 [2, (M-H) ${ }^{+}$], 390.3 [57], 295.2 [100], 277.2 [18], 179.1 [69], 165.0 [64], 57.1 [34]; HRMS (EI) $\mathrm{m} / \mathrm{z}, 407.3292\left(407.3308\right.$ calcd for [M-H] ${ }^{+}$ $\left.\mathrm{C}_{29} \mathrm{H}_{43} \mathrm{O}\right)$. 


\section{9-Biphen-2-yl-heptadecan-9-ol (2b)}

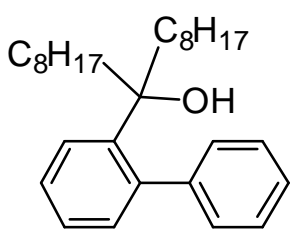

(Route 2, Scheme 1)

$n$-Butyllithium (2.5 M in hexane, $\left.4.3 \mathrm{~cm}^{3}, 10.7 \mathrm{mmol}\right)$ was added slowly to the mixture of 2-iodobiphenyl $3(3.0 \mathrm{~g}, 10.7 \mathrm{mmol})$ and dry tetrahydrofuran $\left(150 \mathrm{~cm}^{3}\right)$ at $-78{ }^{\circ} \mathrm{C}$ over 20 min under nitrogen. The mixture was stirred for $2 \mathrm{~h}$ at the same temperature. 9Heptadecanone $4(2.5 \mathrm{~g}, 9.6 \mathrm{mmol})$ was dissolved in dry tetrahydrofuran $\left(50 \mathrm{~cm}^{3}\right)$ in a separate flask under nitrogen. The 9-heptadecanone $\mathbf{4}$ solution was added via syringe to the mixture slowly over $20 \mathrm{~min}$ at $-78{ }^{\circ} \mathrm{C}$ and stirred overnight at room temperature. The reaction was quenched with an aqueous ammonium chloride solution $\left(10 \% ; 5 \mathrm{~cm}^{3}\right)$ and water $\left(30 \mathrm{~cm}^{3}\right)$ at $0{ }^{\circ} \mathrm{C}$. The organic phase was separated and the aqueous phase was extracted with dichloromethane $\left(20 \mathrm{~cm}^{3}\right)$. The combined organic phases were evaporated under reduced pressure to give the title compound as a crude oil ( $3.9 \mathrm{~g})$. The crude product was used in the next step without further purification. 


\section{9,9-Dioctyl-9H-fluorene (5a)}

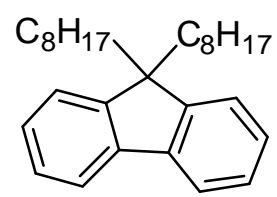

(Route 1, Scheme 1)

Other examples of alkylative cyclization to form fluorenes and derivatives have been reported. ${ }^{27-31}$

To a solution of 9-biphenyl-2-yl-heptadecan-9-ol $\mathbf{2 a}(2.7 \mathrm{~g}, 6.6 \mathrm{mmol})$ in dichloromethane $\left(50 \mathrm{~cm}^{3}\right)$ was added trifluoroboron etherate $\left(0.84 \mathrm{~cm}^{3}, 6.6 \mathrm{mmol}\right)$ slowly via syringe and the solution was stirred overnight at room temperature. The reaction was quenched with methanol $\left(2 \mathrm{~cm}^{3}\right)$ and evaporated under reduced pressure to give a crude oil. The crude oil was purified by column chromatography (petroleum ether $40-60{ }^{\circ} \mathrm{C}$ only) to give the title compound as a colourless oil $(2.5 \mathrm{~g}, 97 \%)$.

${ }^{1} \mathrm{H}$ NMR (500 MHz; $\left.\mathrm{CDCl}_{3}\right) \delta$ 0.64-0.67 (4 H, m), $0.85(6 \mathrm{H}, \mathrm{t}, J=7) 1.07-1.24(20 \mathrm{H}$, m), 1.96-2.00 (4 H, m), 7.29-7.37 (6 H, m), 7.72-7.73 (2 H, m); ${ }^{13} \mathrm{C}$ NMR (125 MHz; $\left.\mathrm{CDCl}_{3}\right) \delta 14.1,22.6,23.7,29.2,29.2,30.0,31.8,40.4,54.9,119.6,122.8,126.6,126.9$, 
141.0, 150.6. The $\delta_{\mathrm{H}}$ and $\delta_{\mathrm{C}}$ data are in agreement with the literature values. ${ }^{32}$

\section{9,9-Dioctyl-9H-fluorene (5b)}

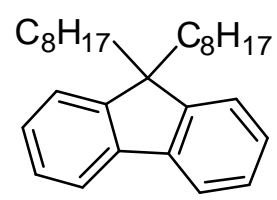

(Route 2, Scheme 1)

The crude product $\mathbf{2 b}$ (3.2 g) of the previous step was dissolved in dichloromethane (50 $\left.\mathrm{cm}^{3}\right)$. Boron trifluoride diethyl etherate $\left(1.2 \mathrm{~cm}^{3}, 9.6 \mathrm{mmol}\right)$ was added to the mixture slowly and stirred overnight at room temperature. The reaction was quenched with methanol $\left(2 \mathrm{~cm}^{3}\right)$ and evaporated under reduced pressure to give a crude oil. The crude oil was purified by column chromatography (petroleum ether $40-60{ }^{\circ} \mathrm{C}$ only) to give the title compound as a colourless oil ( $3 \mathrm{~g}, 80 \%)$.

${ }^{1} \mathrm{H}$ NMR (500 MHz; $\left.\mathrm{CDCl}_{3}\right) \delta$ 0.64-0.67 (4 H, m), $0.85(6 \mathrm{H}, \mathrm{t}, J=7)$ 1.07-1.24 (20 H, m), 1.96-2.00 (4 H, m), 7.29-7.37 (6 H, m), 7.72-7.73 (2 H, m); ${ }^{13} \mathrm{C}$ NMR (125 MHz; $\left.\mathrm{CDCl}_{3}\right) \delta 14.1,22.6,23.7,29.2,29.2,30.0,31.8,40.4,54.9,119.6,122.8,126.6,126.9$, 141.0, 150.6. The $\delta_{\mathrm{H}}$ and $\delta_{\mathrm{C}}$ data are in agreement with the literature values. ${ }^{32}$ 


\section{2,7-Dibromo-9,9-dioctyl-9H-fluorene (6a, 6b)}

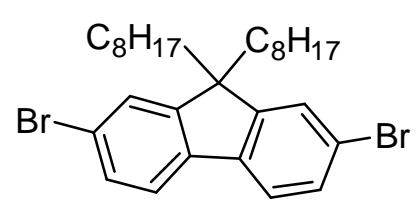

Bromine $\left(0.7 \mathrm{~cm}^{3}, 13.8 \mathrm{mmol}\right)$ was added slowly to a mixture of 9,9-dioctyl-9Hfluorene 5a, 5b $(2.7 \mathrm{~g}, 6.9 \mathrm{mmol})$, iodine $(140.0 \mathrm{mg}, 0.1 \mathrm{mmol})$ and dichloromethane $\left(70 \mathrm{~cm}^{3}\right)$ over $30 \mathrm{~min}$ at $0{ }^{\circ} \mathrm{C}$ in the dark. The mixture was stirred at $0{ }^{\circ} \mathrm{C}$ for $1 \mathrm{~h}$ then at room temperature for $2 \mathrm{~h}$. An aqueous $\mathrm{Na}_{2} \mathrm{~S}_{2} \mathrm{O}_{3}$ solution $\left(10 \%, 5 \mathrm{~cm}^{3}\right)$ and then water $\left(30 \mathrm{~cm}^{3}\right)$ were added to quench the reaction. The organic phase was separated and the aqueous phase was extracted with dichloromethane. The combined organic phases were dried over magnesium sulphate and evaporated under reduced pressure to give a crude solid. The crude material was purified by column chromatography (petroleum ether 40$60{ }^{\circ} \mathrm{C}$ only) and recrystallised from ethanol to give the title compound (2.8 g, $74 \%$ ) as colourless crystals.

mp 53-54 ${ }^{\circ} \mathrm{C}$ (ethanol) [lit., ${ }^{33} 51-54{ }^{\circ} \mathrm{C}$ (hexane)]; ${ }^{1} \mathrm{H} \mathrm{NMR}\left(500 \mathrm{MHz} ; \mathrm{CDCl}_{3}\right) \delta 0.54-$ $0.64(4 \mathrm{H}, \mathrm{m}), 0.83(6 \mathrm{H}, \mathrm{t}, J=7)$ 1.04-1.28 (20 H, m), 1.88-1.93 (4 H, m), 7.43-7.47 (4 
$\mathrm{H}, \mathrm{m}), 7.52(2 \mathrm{H}, \mathrm{d}, J=8) ;{ }^{13} \mathrm{C} \mathrm{NMR}\left(125 \mathrm{MHz} ; \mathrm{CDCl}_{3}\right) \delta 14.0,22.6,23.7,29.1,29.2$, $29.9,31.8,40.2,55.7,121.0,121.5,126.2,130.2,139.1,152.6$. The $\delta_{H}$ and $\delta_{\mathrm{C}}$ data are in agreement with the literature values. ${ }^{32}$

\section{9,9-Dioctyl-2,7-bis(4,4',5,5'-tetramethyl-1,3,2-dioxaborolan-2-yl)-9H-fluorene}

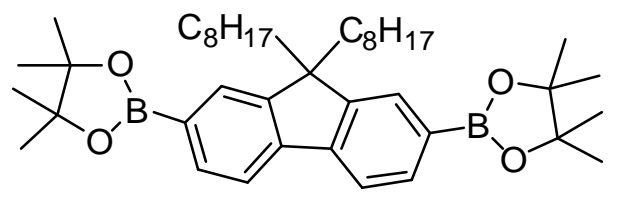

$n$-Butyllithium (2.5 M in hexane; $2.4 \mathrm{~cm}^{3}, 6.0 \mathrm{mmol}$ ) was added slowly over $30 \mathrm{~min}$ to a stirred solution of 2,7-dibromo-9,9-dioctyl-9H-fluorene $6 \mathbf{b}(1.5 \mathrm{~g}, 2.7 \mathrm{mmol})$ in dry tetrahydrofuran $\left(70 \mathrm{~cm}^{3}\right)$ at $-78{ }^{\circ} \mathrm{C}$. The mixture was stirred for $1 \mathrm{~h}$ at the same temperature before 2-isopropoxy-4,4',5,5'-tetramethyl-1,3,2-dioxaborolane $\left(2.0 \mathrm{~cm}^{3}\right.$, $9.8 \mathrm{mmol}$ ) was added slowly over $30 \mathrm{~min}$. The mixture was allowed to warm up slowly to room temperature while it was stirred overnight. The reaction was quenched with water $\left(10 \mathrm{~cm}^{3}\right)$ and the solvent was evaporated under reduced pressure. The residue was dissolved in dichloromethane $\left(50 \mathrm{~cm}^{3}\right)$ and water $\left(20 \mathrm{~cm}^{3}\right)$ and the aqueous phase was extracted with dichloromethane $\left(2 \times 20 \mathrm{~cm}^{3}\right)$. The combined organic phases were dried 
over magnesium sulphate and evaporated under reduced pressure. The crude product was purified by column chromatography (petroleum ether $40-60 \quad{ }^{\circ} \mathrm{C}$ : dichloromethane $=3: 7$ ) and recrystallised from acetone to give the title compound as colour less crystals $(1.0 \mathrm{~g}, 57 \%)$.

mp $129{ }^{\circ} \mathrm{C}$ (acetone) (lit., ${ }^{34} 127-128{ }^{\circ} \mathrm{C}$ (heptane)); ${ }^{1} \mathrm{H}$ NMR $\left(500 \mathrm{MHz} ; \mathrm{CDCl}_{3}\right) \delta$ 0.50$0.60(4 \mathrm{H}, \mathrm{m}), 0.81(6 \mathrm{H}, \mathrm{t}, J=7)$ 0.96-1.23 (20 H, m), $1.39(24 \mathrm{H}, \mathrm{s}), 1.95-2.05(4 \mathrm{H}$, m), $7.72(2 \mathrm{H}, \mathrm{d}, J=8), 7.75(2 \mathrm{H}, \mathrm{s}), 7.81(2 \mathrm{H}, \mathrm{dd}, J=8,1) ;{ }^{13} \mathrm{C}$ NMR $(125 \mathrm{MHz}$; $\left.\mathrm{CDCl}_{3}\right) \delta 14.0,22.6,23.6,24.9,29.1,29.2,29.9,31.8,40.0,55.2,83.7,119.3,119.4$, $128.8,133.5,143.8,150.4$. The $\delta_{\mathrm{H}}$ and $\delta_{\mathrm{C}}$ data are in agreement with the literature values. ${ }^{35}$

\section{a,? -Bis(phenyl)poly(9,9-dioctyl-9H-fluorene-2,7-diyl) (8a)}

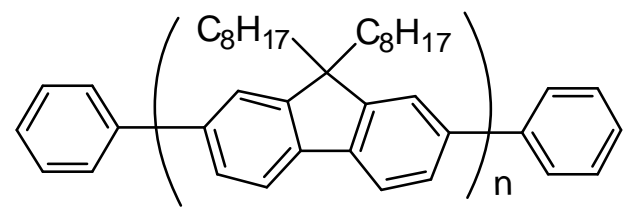

Examples of Yamamoto polymerizations to prepare polyfluorenes have been previously 
reported. $^{36,37}$

To a stirred solution of $\mathrm{Ni}(\mathrm{COD})_{2}(276 \mathrm{mg}, 1.0 \mathrm{mmol})$ and 2,2'-bipyridine $(157 \mathrm{mg}, 1.0$ mmol) in dry dimethylformamide $\left(3.5 \mathrm{~cm}^{3}\right)$ was added COD $\left(123 \mu \mathrm{m}^{3}, 1.0 \mathrm{mmol}\right)$ and the resultant solution was stirred for $1 \mathrm{~h}$ at $75{ }^{\circ} \mathrm{C}$ under nitrogen. 2,7-Dibromo-9,9dioctyl-9H-fluorene $\mathbf{6 a}(0.5 \mathrm{~g}, 0.91 \mathrm{mmol})$ was dissolved in toluene $\left(6 \mathrm{~cm}^{3}\right)$ in a separate flask under nitrogen and then added to the mixture. The mixture was stirred overnight for $24 \mathrm{~h}$ at $75{ }^{\circ} \mathrm{C}$ under nitrogen. Bromobenzene $\left(83 \mu \mathrm{m}^{3}, 0.91 \mathrm{mmol}\right)$ was added to the mixture and stirred for $12 \mathrm{~h}$ under the same conditions. The mixture was dropped slowly by pipette into a stirred solvent mixture (methanol:acetone:con. $\mathrm{HCl}=$ $1: 1: 1 ; 150 \mathrm{~cm}^{3}$ ) and the resultant mixture was stirred for $2 \mathrm{~h}$. The precipitate was filtered and washed with the solvent mixture (methanol:acetone:con. $\mathrm{HCl}=1: 1: 1 ; 50 \mathrm{~cm}^{3}$ ). The precipitate was dissolved in the minimum amount of chloroform and added slowly to a vigorously stirred solution of methanol $\left(100 \mathrm{~cm}^{3}\right)$ to give a fibrous precipitate. The mixture was filtered and washed with methanol $\left(50 \mathrm{~cm}^{3}\right)$. The precipitate was dried under high vacuum to give the title compound as light green fibres (320 mg, 90\%)

Anal. Calcd. for polymer: C, 89.6; H, 10.4. Found: C, 89.3; H, 10.9. IR (neat solid) 2923, 2852, 1458, 1404, 1377, 1255, 1000, 885, 812, 757, $735 \mathrm{~cm}^{-1} ;{ }^{1} \mathrm{H}$ NMR (500 
$\mathrm{MHz} ; \mathrm{CDCl}_{3}$ ) $\delta$ 0.7-1.0 (br m, $\mathrm{CH}_{2}+\mathrm{CH}_{3}$ ) 1.0-1.3 (br m, $\mathrm{CH}_{2}$ ), 1.9-2.3 (br m, $\mathrm{CH}_{2}$ ), 7.58.0 (br m, $\mathrm{Ar} H$ ); ${ }^{13} \mathrm{C}$ NMR $\left(125 \mathrm{MHz} ; \mathrm{CDCl}_{3}\right) \delta 14.1,22.6,23.9,29.2,29.2,30.0,31.8$, $40.4,55.8,120.0,121.5,126.1,140.0,140.5,151.8$; GPC assay in tetrahydrofuran vs. narrow polystyrene standards revealed $M_{\mathrm{w}}=37,400, M_{\mathrm{n}}=21,700, M_{\mathrm{p}}=29,400, \mathrm{PDI}=$ 1.7

Polymer $\mathbf{8 b}$ was synthesised by the same method as 8a using 9,9-dioctyl-9H-fluorene 6b to give the title compound as light green fibres (300 mg, $85 \%$ ).

Anal. Calcd. for polymer: C, 89.6; H, 10.4. Found: C, 89.4; H, 10.5. IR (neat solid) 2923, 2851, 1457, 1402, 1376, 1252, 999, 885, 812, 757, $733 \mathrm{~cm}^{-1} ;{ }^{1} \mathrm{H}$ NMR (500 MHz; $\left.\mathrm{CDCl}_{3}\right) \delta$ 0.7-1.0 (br m, $\mathrm{CH}_{2}+\mathrm{CH}_{3}$ ) 1.0-1.3 (br m, $\mathrm{CH}_{2}$ ), 1.9-2.3 (br m, $\mathrm{CH}_{2}$ ), 7.5-8.0 (br m, $\mathrm{Ar} H) ;{ }^{13} \mathrm{C}$ NMR $\left(125 \mathrm{MHz} ; \mathrm{CDCl}_{3}\right) \delta 14.1,22.6,23.9,29.2,29.2,30.0,31.8,40.4$, $55.3,120.0,121.5,126.1,140.0,140.5,151.8 ;$ GPC assay in tetrahydrofuran vs. narrow polystyrene standards revealed $M_{\mathrm{w}}=25,000, M_{\mathrm{n}}=9,800, M_{\mathrm{p}}=27,000, \mathrm{PDI}=2.6$;

Polymer 8c was synthesised by the same method as 8a using conventional 9,9-dioctyl$9 H$-fluorene ${ }^{38,39} \mathbf{6 c}$ to give the title compound as light green fibres (280 mg, $79 \%$ ). 
Anal. Calcd. for polymer: C, 89.6; H, 10.4. Found: C, 89.1; H, 10.9. IR (neat solid) 2954, 2923, 2852, 1458, 1404, 1377, 1254, 1000, 885, 812, 757, $721 \mathrm{~cm}^{-1} ;{ }^{1} \mathrm{H}$ NMR (500 MHz; $\mathrm{CDCl}_{3}$ ) $\delta$ 0.7-1.0 (br m, $\mathrm{CH}_{2}+\mathrm{CH}_{3}$ ) 1.0-1.3 (br m, $\mathrm{CH}_{2}$ ), 1.9-2.3 (br m, $\mathrm{CH}_{2}$ ), 7.5-8.0 (br m, $\mathrm{Ar} H$ ); ${ }^{13} \mathrm{C}$ NMR (125 MHz; $\left.\mathrm{CDCl}_{3}\right) \delta$ 14.1, 22.6, 23.9, 29.2, 29.2, 30.0, $31.8,40.4,55.3,120.0,121.5,126.1,140.0,140.5,151.8$; GPC assay in tetrahydrofuran vs. narrow polystyrene standards revealed $M_{\mathrm{w}}=39,800, M_{\mathrm{n}}=18,300, M_{\mathrm{p}}=41,900$, PDI $=2.2$

\section{a,? -Bis(phenyl)poly(9,9-dioctyl-9H-fluorene -2,7-diyl) (8d)}

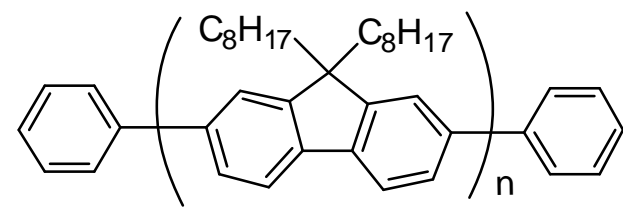

To a Schlenk tube was added 2,7-dibromo-9,9-dioctyl-9H-fluorene $6 \mathbf{b}$ (353 mg, 0.64 mmol), 9,9-dioctyl-2,7-bis(4,4',5,5'-tetramethyl-1,3,2-dioxaborolan-2-yl)-9H-fluorene 7b (414 mg, $0.64 \mathrm{mmol}$ ) and tetrakis(triphenylphosphine) palladium (7 mg, $0.04 \mathrm{mmol}$ ) under a nitrogen atmosphere. Toluene $\left(15 \mathrm{~cm}^{3}\right)$ was added to the mixture and the resultant mixture was stirred at $90{ }^{\circ} \mathrm{C}$ for $5 \mathrm{~min}$ before an aqueous tetraethyl ammonium 
Polyfluorenes Without Monoalkylfluorene Defects. Supporting Information. ( ja074634i)

hydroxide solution $\left(2 \mathrm{~cm}^{3}\right)$ was added. The mixture was stirred for $24 \mathrm{~h}$ at $90{ }^{\circ} \mathrm{C}$ under nitrogen. Bromobenzene $\left(0.07 \mathrm{~cm}^{3}, \mathrm{mmol}\right)$ was added to the mixture and stirred at $90{ }^{\circ} \mathrm{C}$ for $12 \mathrm{~h}$. Phenylboronic acid $(157 \mathrm{mg}, 1.29 \mathrm{mmol})$ was added to the mixture after which the mixture was stirred for $12 \mathrm{~h}$. The mixture was cooled down to room temperature and dropped by pipette into a stirred solution of methanol $\left(100 \mathrm{~cm}^{3}\right)$ in an open vessel. The precipitate was isolated and dissolved in dichloromethane. The solution was passed through a pad of silica. The collected dichloromethane solution was concentrated under reduced pressure and added dropwise to a vigorously stirred solution of methanol $\left(100 \mathrm{~cm}^{3}\right)$ in an open vessel. The precipitate was filtered and washed with methanol $\left(50 \mathrm{~cm}^{3}\right)$ on a filter funnel. The precipitate was dried under high vacuum to give the title compound as light green fibres (430 mg, $86 \%$ ).

Anal. Calcd. for polymer: C, 89.6; H, 10.4. Found: C, 89.1; H, 10.8. IR (neat solid) 2924, 2852, 1458, 1377, 1275, 1259, 1000, 885, 812, $750 \mathrm{~cm}^{-1} ;{ }^{1} \mathrm{H}$ NMR $(500 \mathrm{MHz}$; $\mathrm{CDCl}_{3}$ ) $\delta$ 0.7-1.0 (br m, $\mathrm{CH}_{2}+\mathrm{CH}_{3}$ ) 1.0-1.3 (br m, $\mathrm{CH}_{2}$ ), 1.9-2.3 (br m, $\mathrm{CH}_{2}$ ), 7.5-8.0 (br m, $\mathrm{Ar} H) ;{ }^{13} \mathrm{C}$ NMR $\left(125 \mathrm{MHz} ; \mathrm{CDCl}_{3}\right) \delta 14.1,22.6,23.9,29.2,29.2,30.0,31.8,40.4$, $55.3,120.0,121.5,126.1,140.0,140.5,151.8$; GPC assay in tetrahydrofuran vs. narrow polystyrene standards revealed $M_{\mathrm{w}}=21,100, M_{\mathrm{n}}=6,000, M_{\mathrm{p}}=27,200, \mathrm{PDI}=3.5$; 


\section{9-Octyl-9H-fluorene ${ }^{35}$}

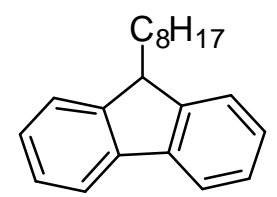

A mixture of $9 H$-fluorene $(7.0 \mathrm{~g}, 42.1 \mathrm{mmol})$, potassium hydroxide $(1.2 \mathrm{~g}, 21.1 \mathrm{mmol})$ and octan-1-ol (28.5 g, $0.31 \mathrm{mmol})$ was stirred overnight in a $100 \mathrm{~cm}^{3}$ Chemware PFA (perfluoroalkoxy) Erlenmeyer flask at $190{ }^{\circ} \mathrm{C}$. The mixture was cooled to room temperature before being purified by dry fash chromatography (petroleum ether 40$60{ }^{\circ} \mathrm{C}$ only) to give the title compound as a colourless liquid (10.8 g, $\left.92 \%\right)$.

${ }^{1} \mathrm{H}$ NMR (500 MHz; $\left.\mathrm{CDCl}_{3}\right) \delta 0.95(3 \mathrm{H}, \mathrm{t}, J=7), 1.23-1.40(12 \mathrm{H}, \mathrm{m}), 2.03-2.11(2 \mathrm{H}$, m), $4.04(1 \mathrm{H}, \mathrm{t}, J=6), 7.34(2 \mathrm{H}, \mathrm{ddd}, J=7,7,1), 7.39(2 \mathrm{H}, \mathrm{dd}, J=7,7), 7.55(2 \mathrm{H}, \mathrm{d}$, $J=7), 7.79(2 \mathrm{H}, \mathrm{d}, J=7) ;{ }^{13} \mathrm{C} \mathrm{NMR}\left(125 \mathrm{MHz} ; \mathrm{CDCl}_{3}\right) \delta$ 14.0, 22.6, 25.7, 29.3, 29.4, $30.0,31.8,33.1,47.5,119.7,124.3,126.7,126.8,141.1,147.6$. The $\delta_{H}$ and $\delta_{\mathrm{C}}$ data are in agreement with the literature values. ${ }^{35}$ 


\section{2,7-Dibromo-9-octyl-9H-fluorene ${ }^{35}$ (9)}

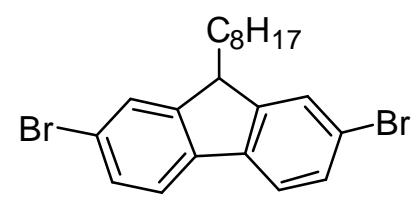

Bromine $\left(1.5 \mathrm{~cm}^{3}, 28.7 \mathrm{mmol}\right)$ was added dropwise over $10 \mathrm{~min}$ to a stirred solution of 9-octyl-9H-fluorene $(4.0 \mathrm{~g}, \quad 14.4 \mathrm{mmol})$ and iodine $(0.3 \mathrm{~g}, 1.1 \mathrm{mmol})$ in dichloromethane $\left(30 \mathrm{~cm}^{3}\right)$ at $0{ }^{\circ} \mathrm{C}$ in the dark. The mixture was stirred for $0.5 \mathrm{~h}$ at the same temperature and then for $2.5 \mathrm{~h}$ at room temperature in the dark before it was quenched with an aqueous sodium thiosulfate solution $\left(20 \% ; 5 \mathrm{~cm}^{3}\right)$. The organic phase was separated, dried over magnesium sulphate and evaporated under reduced pressure. The crude product was recrystallised from ethanol to give the title compound as a white solid $(4.7 \mathrm{~g}, 75 \%)$.

mp 77-80 ${ }^{\circ} \mathrm{C}$ (ethanol) (lit., ${ }^{35}$ 77-80 ${ }^{\circ} \mathrm{C}$ (ethanol)); ${ }^{1} \mathrm{H}$ NMR $\left(400 \mathrm{MHz} ; \mathrm{CDCl}_{3}\right) \delta 0.86(3$ H, t, $J=7), 1.06-1.35(12 \mathrm{H}, \mathrm{m}), 1.90-2.04(2 \mathrm{H}, \mathrm{m}), 3.95(1 \mathrm{H}, \mathrm{t}, J=6), 7.48(2 \mathrm{H}, \mathrm{dd}$, $J=8,2), 7.56(2 \mathrm{H}, \mathrm{d}, J=8), 7.62(2 \mathrm{H}, \mathrm{br} \mathrm{s}) ;{ }^{13} \mathrm{C} \mathrm{NMR}\left(100 \mathrm{MHz} ; \mathrm{CDCl}_{3}\right) \delta$ 14.1, 22.6, $25.4,29.2,29.3,29.8,31.8,32.6,47.5,121.1,121.1,127.6,130.2,139.1,149.3$. The $\delta_{H}$ 
and $\delta_{\mathrm{C}}$ data are in agreement with the literature values. ${ }^{35}$

\section{a,? -Bis(phenyl)poly(9,9-dioctyl-9H-fluorene-2,7-diyl)-co-(9-dioctyl-9H-fluorene-}

2,7-diyl) (10)

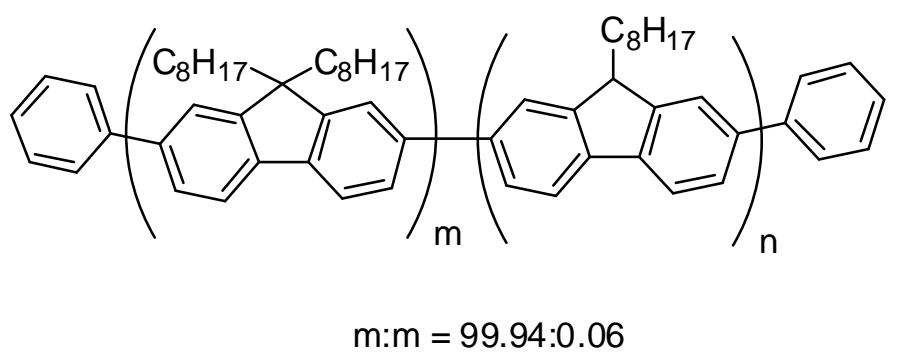

To a mixture of $\mathrm{Ni}(\mathrm{COD})_{2}(276 \mathrm{mg}, 1.0 \mathrm{mmol}), 2,2^{\prime}$-bipyridine $(157 \mathrm{mg}, 1.0 \mathrm{mmol})$ and dry dimethylformamide $\left(3.5 \mathrm{~cm}^{3}\right)$ was added COD $\left(123 \mu \mathrm{m}^{3}, \quad 1.0 \mathrm{mmol}\right)$ and the solution was stirred for $1 \mathrm{~h}$ at $75{ }^{\circ} \mathrm{C}$ under nitrogen. 2,7-Dibromo-9,9-dioctyl-9Hfluorene $6 \mathbf{b}(0.5 \mathrm{~g}, 0.91 \mathrm{mmol})$ was dissolved in toluene $\left(6 \mathrm{~cm}^{3}\right)$ in a separate flask under nitrogen and then added to the mixture. 2,7-Dibromo-9-octyl-9H-fluorene $9(0.25$ $\mathrm{g}, 0.57 \mathrm{mmol})$ was dissolved in toluene $\left(100 \mathrm{~cm}^{3}\right)$ in a separate flask under nitrogen and $0.1 \mathrm{~cm}^{3}(0.25 \mathrm{mg}$ of $9,0.57 \mu \mathrm{mol})$ was taken via syringe and added to the mixture. The mixture was stirred overnight for $24 \mathrm{~h}$ at $75{ }^{\circ} \mathrm{C}$ under nitrogen. Bromobenzene $\left(83 \mu \mathrm{m}^{3}\right.$, $0.91 \mathrm{mmol}$ ) was added to the mixture and stirred for $12 \mathrm{~h}$ under the same condition. The mixture was poured slowly to the solvent mixture (methanol:acetone:con. $\mathrm{HCl}=1: 1: 1$; 
Polyfluorenes Without Monoalkylfluorene Defects. Supporting Information. ( ja074634i)

$150 \mathrm{~cm}^{3}$ ) and stirred for $2 \mathrm{~h}$. The mixture was filtered and washed with the solvent mixture (methanol:acetone:con. $\mathrm{HCl}=1: 1: 1 ; 50 \mathrm{~cm}^{3}$ ). The precipitate was dissolved in the minimum amount of chloroform and added slowly to a vigorously stirred solution of methanol $\left(50 \mathrm{~cm}^{3}\right)$. The precipitate was filtered and washed with methanol $\left(50 \mathrm{~cm}^{3}\right)$ on filter funnel. The precipitate was dried under high vacuum to give the title compound as light green fibres (300 mg, $85 \%)$.

Anal. Calcd. for polymer: C, 89.6; H, 10.4. Found: C, 89.3; H, 10.9. IR (neat solid) 2923, 2852, 1458, 1404, 1377, 1256, 1000, 908, 885, 812, 757, $734 \mathrm{~cm}^{-1} ;{ }^{1} \mathrm{H}$ NMR (500 $\mathrm{MHz}, \mathrm{CDCl}_{3}$ ) $\delta$ 0.7-1.0 (br m, $\mathrm{CH}_{2}+\mathrm{CH}_{3}$ ) 1.0-1.3 (br m, $\mathrm{CH}_{2}$ ), 1.9-2.3 (br m, $\mathrm{CH}_{2}$ ), 7.58.0 (br m, $\mathrm{Ar} H) ;{ }^{13} \mathrm{C} \mathrm{NMR}\left(125 \mathrm{MHz} ; \mathrm{CDCl}_{3}\right) \delta 14.1,22.6,23.9,29.2,29.2,30.0,31.8$, $40.4,55.8,120.0,121.5,126.1,140.0,140.5,151.8$; GPC assay in tetrahydrofuran vs. narrow polystyrene standards revealed $M_{\mathrm{w}}=71,000, M_{\mathrm{n}}=38,300, M_{\mathrm{p}}=68,400$, PDI $=$ 1.9 


\section{a,? -Bis(phenyl)poly(9,9-dioctyl-9H-fluorene -2,7-diyl)-co-(9-dioctyl-9H-fluorene -}

2,7-diyl) (11)

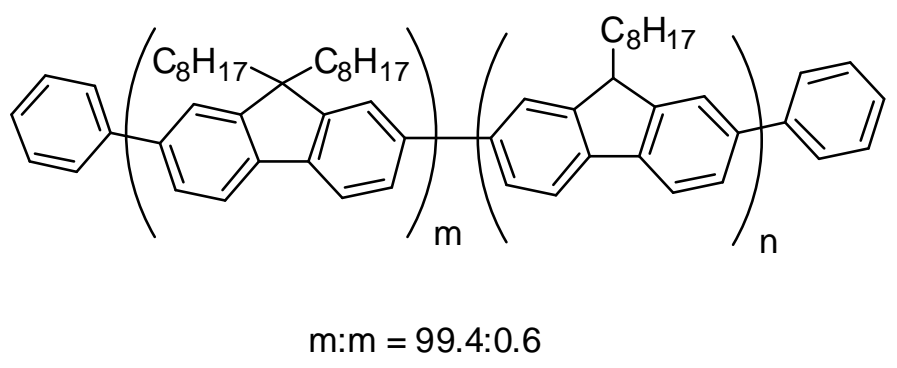

To a mixture of $\mathrm{Ni}(\mathrm{COD})_{2}(276 \mathrm{mg}, 1.0 \mathrm{mmol}), 2,2^{\prime}$-bipyridine $(157 \mathrm{mg}, 1.0 \mathrm{mmol})$ and dry dimethlyformamide $\left(3.5 \mathrm{~cm}^{3}\right)$ was added COD $\left(123 \mu \mathrm{m}^{3}, \quad 1.0 \mathrm{mmol}\right)$ and the solution was stirred for $1 \mathrm{~h}$ at $75{ }^{\circ} \mathrm{C}$ under nitrogen. 2,7-Dibromo-9,9-dioctyl-9Hfluorene $6 \mathbf{b}(0.5 \mathrm{~g}, 0.91 \mathrm{mmol})$ was dissolved in toluene $\left(6 \mathrm{~cm}^{3}\right)$ in a separate flask under nitrogen then added to the mixture. 2,7-Dibromo-9-octyl-9H-fluorene 9 (0.25 g, $0.57 \mathrm{mmol})$ was dissolved in toluene $\left(100 \mathrm{~cm}^{3}\right)$ in a separate flask under nitrogen and 1 $\mathrm{cm}^{3}(2.5 \mathrm{mg}$ of 9, $5.7 \mu \mathrm{mol})$ was taken via syringe and added to the mixture. The mixture was stirred overnight for $24 \mathrm{~h}$ at $75{ }^{\circ} \mathrm{C}$ under nitrogen. Bromobenzene $\left(83 \mu \mathrm{m}^{3}\right.$, $0.91 \mathrm{mmol}$ ) was added to the mixture and stirred for $12 \mathrm{~h}$ under the same condition. The mixture was poured slowly to the solvent mixture (methanol:acetone:con. $\mathrm{HCl}=1: 1: 1$; $150 \mathrm{~cm}^{3}$ ) and stirred for $2 \mathrm{~h}$. The mixture was filtered and washed with the solvent mixture (methanol:acetone:con. $\mathrm{HCl}=1: 1: 1 ; 50 \mathrm{~cm}^{3}$ ). The precipitate was dissolved in 
the minimum amount of chloroform and added slowly to a vigorously stirred solution of methanol $\left(50 \mathrm{~cm}^{3}\right)$. The precipitate was filtered and washed with methanol $\left(50 \mathrm{~cm}^{3}\right)$ on filter funnel. The precipitate was dried under high vacuum to give title compound as light green fibre (310 mg, $87 \%)$.

Anal. Calcd. for polymer: C, 89.6; H, 10.4. Found: C, 88.8; H, 11.5. IR (neat solid) 2923, 2852, 1458, 1404, 1377, 1259, 1000, 885, 812, 750, $735 \mathrm{~cm}^{-1} ;{ }^{1} \mathrm{H}$ NMR $(500$ $\mathrm{MHz} ; \mathrm{CDCl}_{3}$ ) $\delta$ 0.7-1.0 (br m, $\mathrm{CH}_{2}+\mathrm{CH}_{3}$ ) 1.0-1.3 (br m, $\mathrm{CH}_{2}$ ), 1.9-2.3 (br m, $\mathrm{CH}_{2}$ ), 7.58.0 (br m, $\mathrm{Ar} H$ ); ${ }^{13} \mathrm{C}$ NMR $\left(125 \mathrm{MHz} ; \mathrm{CDCl}_{3}\right) \delta 14.1,22.6,23.9,29.2,29.2,30.0,31.8$, $40.4,55.8,120.0,121.5,126.1,140.0,140.5,151.8$; GPC assay in tetrahydrofuran vs. narrow polystyrene standards revealed $M_{\mathrm{w}}=64,600, M_{\mathrm{n}}=33,000, M_{\mathrm{p}}=63,100$, PDI $=$ 2.0

\section{Electroluminescent device fabrication}

ITO coated glass (a gift from CDT) was cleaned by successive sonication in detergent,

1:1 hydrogen peroxide/ammonia and then distilled water. The PEDOT/PSS (Aldrich, $2.8 \mathrm{wt} \%$ solution) was filtered $(0.45 \mu \mathrm{m})$ and deposited by spin coating at $5000 \mathrm{rpm}$ for $60 \mathrm{sec}$ to give a $75 \mathrm{~nm}$ layer. The PEDOT/PSS layer was then annealed in an oven at $100{ }^{\circ} \mathrm{C}$ for $1 \mathrm{hr}$. Solutions of the poly $(9,9$-dioctylfluorene $)$ s in toluene $(15 \mathrm{mg} / \mathrm{mL})$ were 
Polyfluorenes Without Monoalkylfluorene Defects. Supporting Information. ( ja074634i)

deposited onto the PEDOT/PSS layer by spin coating. The solutions were filtered $(0.2$ $\mu \mathrm{m})$ and then spun at $3000 \mathrm{rpm}$ for $30 \mathrm{sec}$. The films were annealed at $80{ }^{\circ} \mathrm{C}$ for $30 \mathrm{~min}$. Spinning conditions and film thicknesses were optimised for each batch of poly $(9,9-$ dioctylfluorene). In each case the thickness of the poly(9,9-dioctylfluorene) layer was $65 \pm 5 \mathrm{~nm}$. All polymer layers were deposited and annealed in air. The cured substrates were transferred to a vacuum evaporator inside a glovebox $\left(\mathrm{H}_{2} \mathrm{O}\right.$ and $\mathrm{O}_{2}$ levels both $<1$ ppm). A layer of $\operatorname{LiF}(0.2 \mathrm{~nm})$ and then $\mathrm{Al}(100 \mathrm{~nm})$ were deposited by thermal evaporation at pressures below $2 \times 10^{-6}$ mbar.

Films were spin coated using a Laurell WS-400B-6NPP Lite single wafer spin processor. A constant acceleration of $10920 \mathrm{rpm}$ was used for all samples. Film thicknesses were determined using a Dektak 6M Profilometer. Electroluminescent devices were tested inside the glovebox $\left(\mathrm{H}_{2} \mathrm{O}\right.$ and $\mathrm{O}_{2}$ levels both $\left.<1 \mathrm{ppm}\right)$. Devices were operated using a Kethley 2400 Sourcemeter. The brightness was measured using a Minolta LS-110 Luminance meter. Electroluminescence spectra were recorded using an Ocean Optics USB2000 spectrometer fitted with an optical fibre. The turn-on-voltage was defined as the voltage corresponding to a luminance of $1 \mathrm{~cd} / \mathrm{m}^{2}$. CIE coordinates for the devices at their turn on voltage are $8 \mathbf{a}(0.21,0.22), \mathbf{8 b}(0.20,0.21), \mathbf{8 c}(0.25$, 
Polyfluorenes Without Monoalkylfluorene Defects. Supporting Information. ( ja074634i)

$0.36)$ and $8 \mathbf{d}(0.17,0.15)$. Subtle shifts in CIE coordinates are probably a consequence of the different end-capping effects. ${ }^{41}$ 


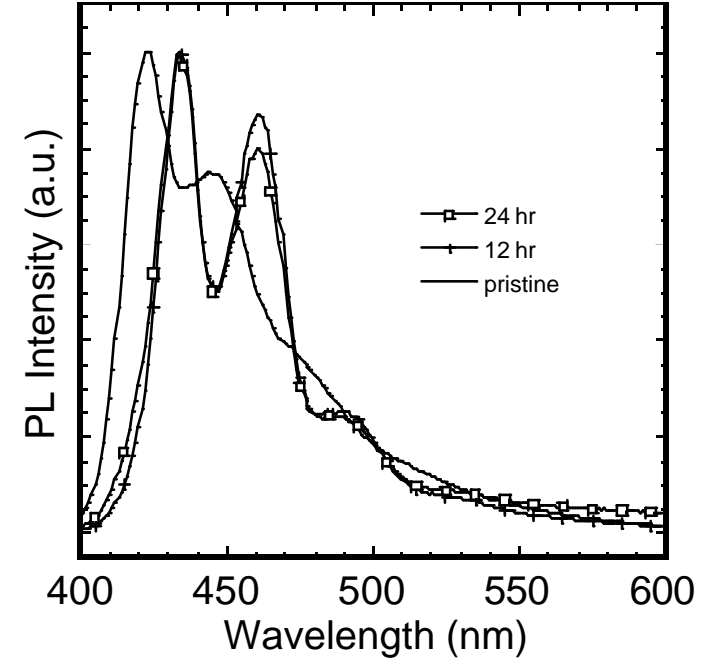

(a)

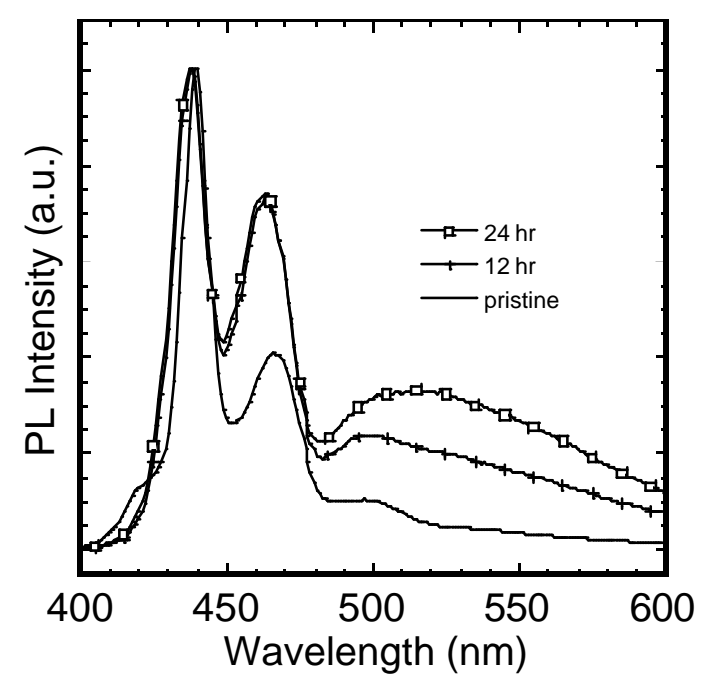

(c)

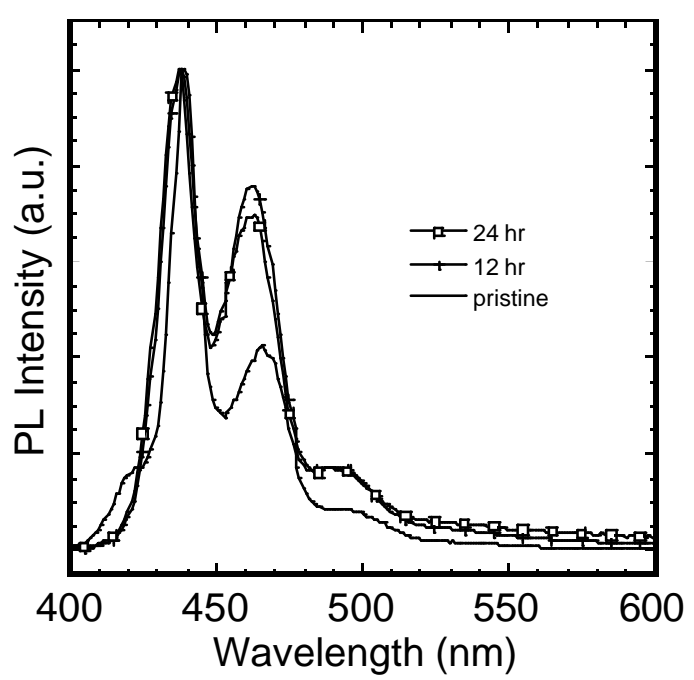

(b)

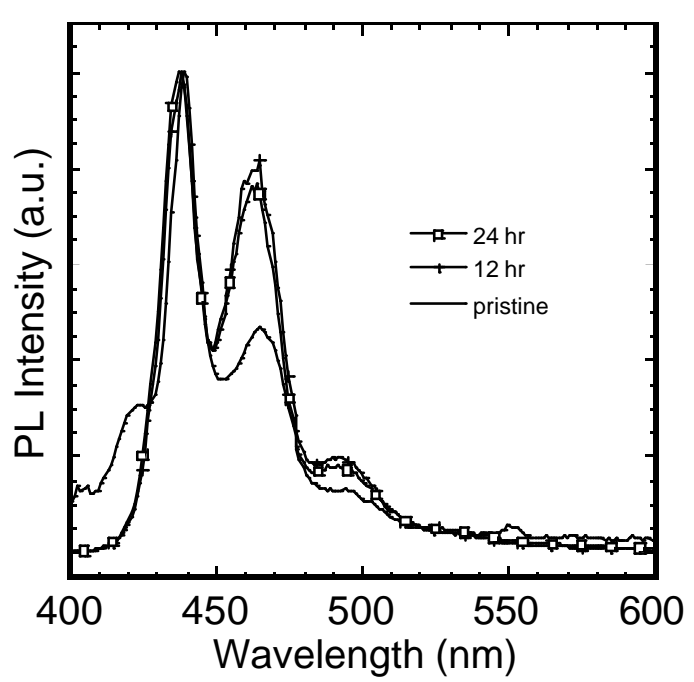

(d)

Figure S1. Photoluminescence spectra of polymers $8 \mathbf{a}, 8 \mathbf{b}, \mathbf{8 c}$ and $8 \mathrm{~d}$ respectively recorded at room temperature in air. Curve (-) pristine; Curve (+) after thermal annealing of the polymers at $110{ }^{\circ} \mathrm{C}$ in air for $12 \mathrm{~h}$; Curve (?) after thermal annealing of the polymers at $110{ }^{\circ} \mathrm{C}$ in air for $24 \mathrm{~h}$. The characteristic vibronic transition peaks at 438 and $466 \mathrm{~nm}$ are indicative of the $\beta$-phase. ${ }^{17,40-42}$ 


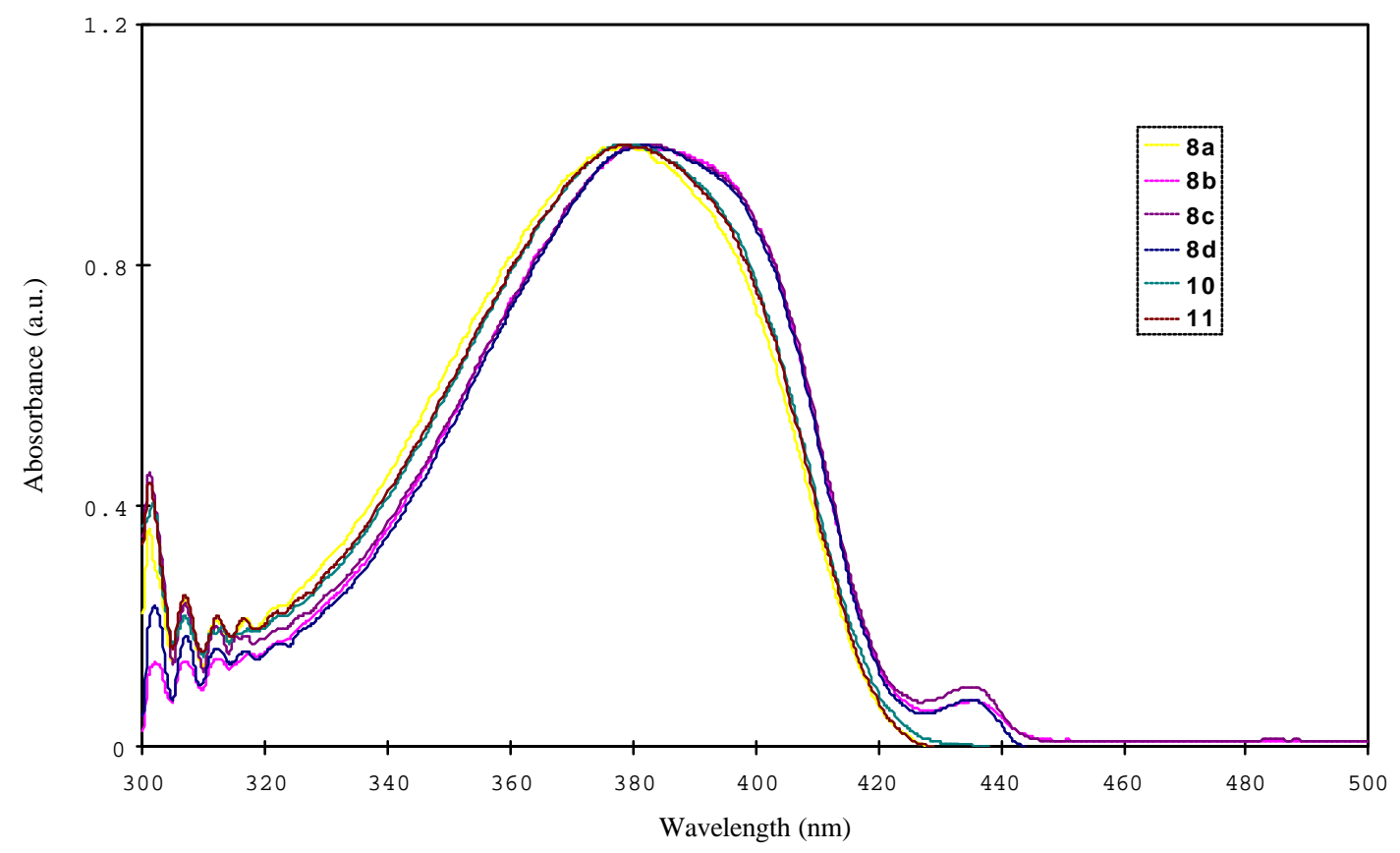

Figure S2. UV-Vis spectra of polymers. 8a-d, 10 and 11. 


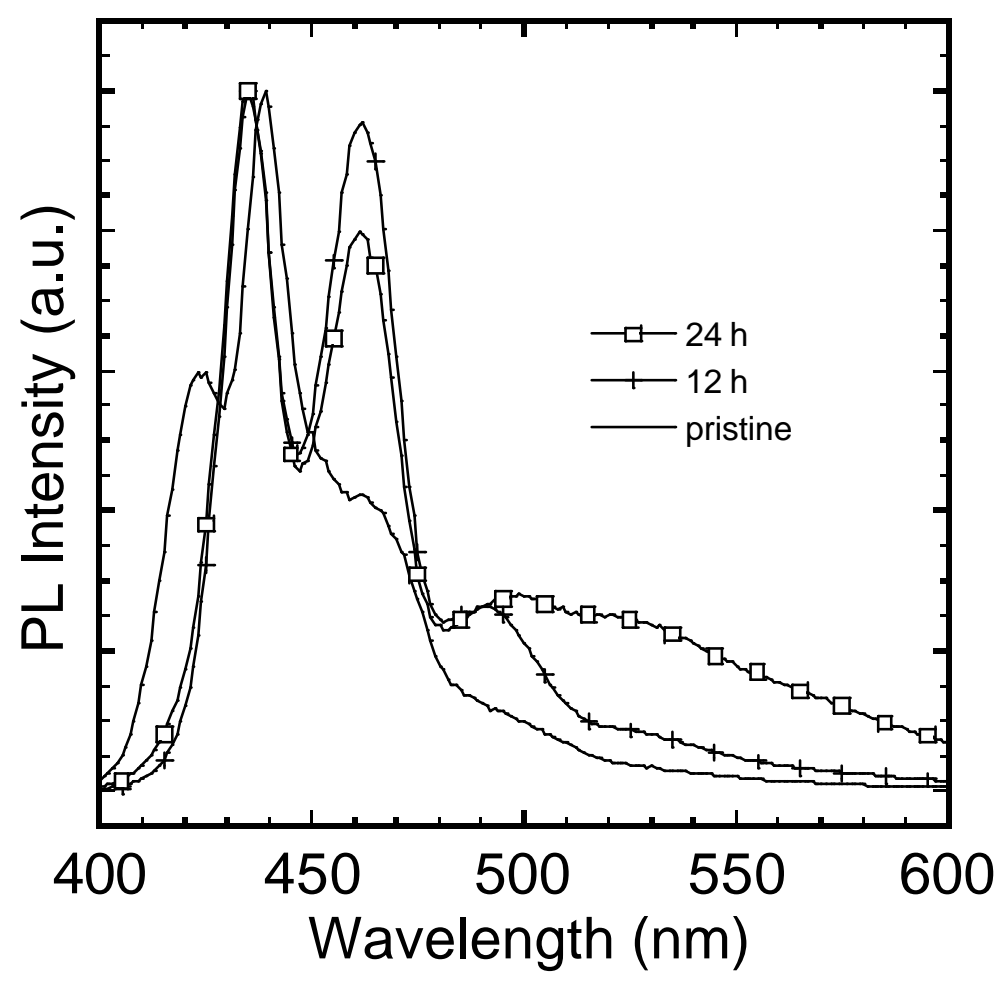

Figure S3. Photoluminescence spectra of polymer 10, pristine $(-), 12 \mathrm{~h}$ at $110{ }^{\circ} \mathrm{C}(+)$, $24 \mathrm{~h}$ at $110^{\circ} \mathrm{C}(?)$.

The red shift in the PL spectra of $\mathbf{1 1}$ (see Figure 1(b)) compared with $\mathbf{1 0}$ is similar to the effect observed by Kulkarni et al. who ascribed this to extended conjugation as a result of the increased proportion of fluorenone units. ${ }^{19}$ 


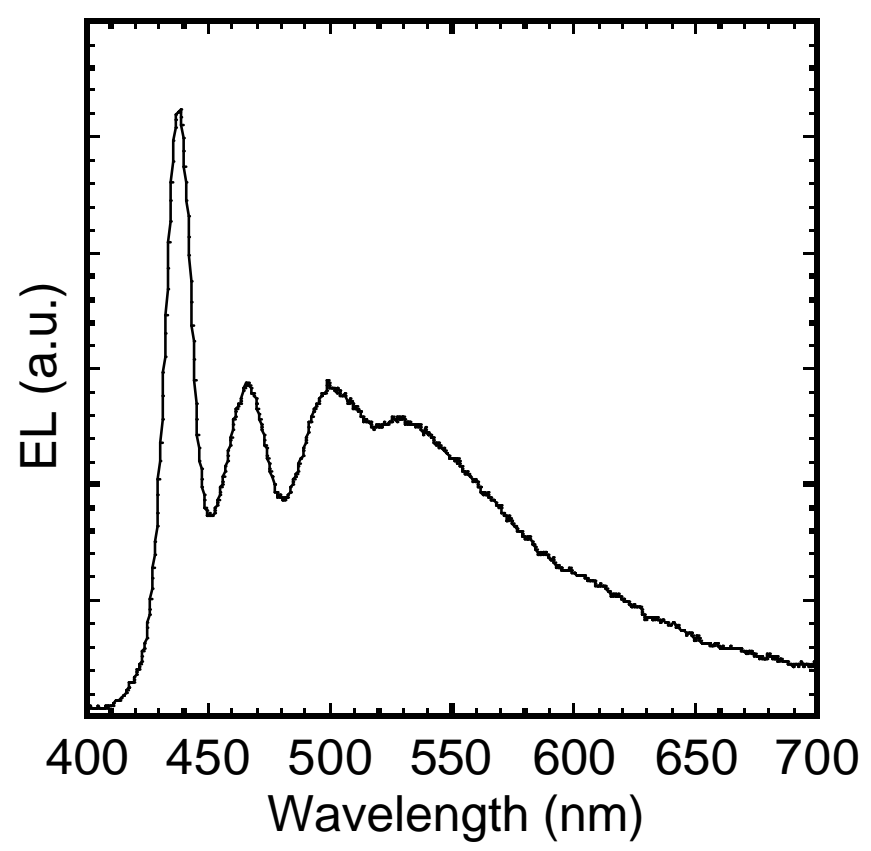

Figure S4. Electroluminescence spectrum of polymer 10 at the turn-on voltage. Device configuration ITO/PEDOT:PSS (70 nm)/Polymer (65 nm)/LiF (0.2 nm)/Al(100 nm).

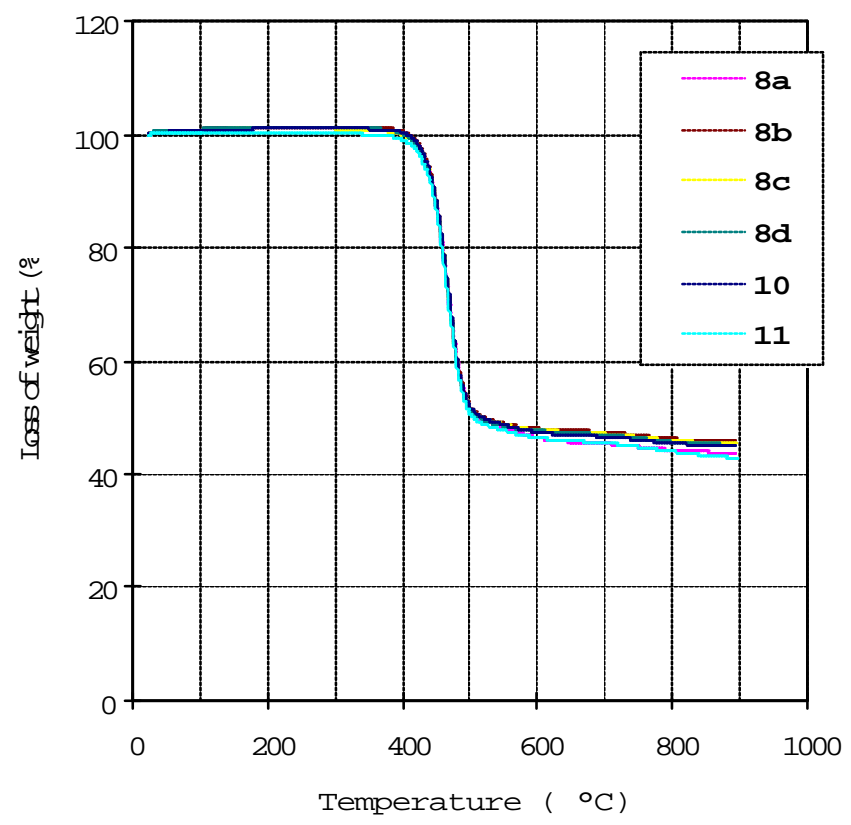

Figure S5. TGA graph of polymers 8a-d, 10 and 11. 


\section{References}

(1) Segura, J. L. Acta Polym. 1998, 49, 319.

(2) Friend, R. H.; Gymer, R. W.; Holmes, A. B.; Burroughes, J. H.; Marks, R. N.; Taliani, C.; Bradley, D. D. C.; DosSantos, D. A.; Brédas, J. L.; Lögdlund, M.; Salaneck, W. R. Nature 1999, 397, 121.

(3) Bernius, M. T.; Inbasekaran, M.; O'Brien, J.; Wu, W. S. Adv. Mater. 2000, 12 , 1737.

(4) Mitschke, U.; Bauerle, P. J. Mater. Chem. 2000, 10, 1471.

(5) Rees, I. D.; Robinson, K. L.; Holmes, A. B.; Towns, C. R.; O'Dell, R. MRS Bull. 2002, 27, 451 .

(6) Scherf, U.; List, E. J. W. Adv. Mater. 2002, 14, 477.

(7) Klärner, G.; Davey, M. H.; Chen, W.-D.; Scott, J. C.; Miller, R. D. Adv. Mater. 1998, 10, 993.

(8) Setayesh, S.; Grimsdale, A. C.; Weil, T.; Enkelmann, V.; Müllen, K.; Meghdadi, F.; List, E. J. W.; Leising, G. J. Am. Chem. Soc. 2001, 123, 946.

(9) Pogantsch, A. F.; Wenzl, F. P.; List, E. W. J.; Leising, G.; Grimsdale, A. C.; Müllen, K. Adv. Mater. 2002, 14, 1061.

(10) Wallace, P.; Towns, C.; Pounds, T. WO 2004/039912 A1, Chem. Abstr. 2004, $140,391624$.

(11) Sainova, D.; Miteva, T.; Nothofer, H.-G.; Scherf, U.; Glowacki, I.; Ulanski, J.; Fujikawa, H.; Neher, D. Appl. Phys. Lett. 2000, 76, 1810.

(12) Craig, M. R.; de Kok, M. M.; Hofstraat, J. W.; Schenning, A. P. H. J.; Meijer, E. W. J. Mater. Chem. 2003, 13, 2861.

(13) Marsitzky, D.; Vestberg, R.; Blainey, P.; Tang, B. T.; Hawker, C. J.; Carter, K. R. J. Am. Chem. Soc. 2001, 123, 6965.

(14) Lim, S.-F.; Friend, R. H.; Rees, I. D.; Li, J.; Ma, Y.; Robinson, K.; Holmes, A. B.; Hennebicq, E.; Beljonne, D.; Cacialli, F. Adv. Funct. Mater. 2005, 15, 981.

(15) Jen, A. K.-Y.; Liu, Y.; Hu, Q.-S.; Pu, L. Appl. Phys. Lett. 1999, 75, 3745.

(16) Mieva, T.; Meissel, A.; Knoll, W.; Nothofer, H.; Scherf, U.; Müller, D. C.; Meerholz, K.; Yasuda, A.; Neher, D. Adv. Mater. 2001, 13, 565.

(17) Hung, M.-C.; Liao, J.-L.; Chen, S. A.; Chen, S.-H.; Su, A.-C. J. Am. Chem. Soc. 2005, 127, 14576.

(18) Li, J.; Hirayama, Y.; Sano, T.; Tomita, T.; Fujii, H.; Wakisaka, K. Thin Solid Films 2006, 515, 2686.

(19) Kulkarni, A. P.; Kong, X.; Jenekhe, S. A. J. Phys. Chem. B. 2004, 108, 8689.

(20) Jo, J.; Chi, C.; Höger, S.; Wegner, G.; Yoon, D. Y. Chem Eur. J. 2004, 10, 2681. 
(21) Chi, C.; Im, C.; Enkelmann, V.; Ziegler, A.; Lieser, G.; Wegner, G. Chem Eur. J. 2005, 11, 6833 .

(22) Li, J.; Li, M.; Bo, Z. Chem Eur. J. 2005, 11, 6930.

(23) Zim, D.; Lando, V. R.; Dupont, J.; Monteiro, A. L. Org. Lett. 2001, 3, 3049.

(24) Poriel, C.; Ferrand, Y.; Juillard, S.; Le Maux, P.; Simonneaux, G. Tetrahedron 2004, 60, 145 .

(25) Arisawa, M.; Torisawa, Y.; Kawahara, M.; Yamanaka, M.; Nishida, A.; Nakagawa, M. J. Org. Chem. 1997, 62, 4327.

(26) Katritzky, A. R; Lang, H. Y.; Wang, Z. Q.; Lie, Z. J. Org. Chem. 1996, 61, 7551 .

(27) Clarkson, R. G.; Gomberg, M. J. Am. Chem. Soc. 1930, 52, 2881.

(28) Jacob, J.; Zhang, J.; Grimsdale, A. C.; Müllen, K.; Gaal, M.; List, E. J. W. Macromolecules 2003, 36, 8240.

(29) Jacob, J.; Sax, S.; Piok, T.; List, E. J. W.; Grimsdale, A. C.; Müllen, K. J. Am. Chem. Soc. 2004, 126, 6987.

(30) Jacob, J.; Grimsdale, A. C.; Müllen, K.; Sax, S.; Gaal, M.; List, E. J. W. Macromolecules 2005, 38, 9933.

(31) Schindler, F.; Jacob, J.; Grimsdale, A. C.; Scherf, U.; Müllen, K.; Lupton, J. M.; Feldman, J. Angew. Chem. Int. Ed. 2005, 44, 1520.

(32) Ranger, M.; Leclere, M. Can. J. Chem. 1998, 76, 1571.

(33) Ding, J.; Day, M.; Robertson, G.; Roovers, J. Macromolecules 2002, 35, 3474.

(34) Pasini, M.; Destri, S.; Porzio, W.; Botta, C.; Giovanella, U. J. Mater. Chem. 2003, 13, 807 .

(35) Evans, N. R.; Devi, L. S.; Mak, C. S. K.; Watkins, S. E.; Pascu, S. I.; Köhler, A.; Friend, R. H.; Williams, C. K.; Holmes, A. B. J. Am. Chem. Soc. 2006, 128, 6647.

(36) Yamamoto, T. Prog. Polym. Sci. 1992, 17, 1153.

(37) Ego, C.; Grimsdale, A. C.; Uckert, F.; Yu, G.; Srdanov, G.; Müllen, K. Adv. Mater. 2002, 14, 809.

(38) Yang, J.; Jiang, C. Y.; Zhang, Y.; Yang, R. Q.; Yang, W.; Hou, Q.; Cao, Y. Macromolecules 2004, 37, 1211.

(39) Woo, E. P.; Inbasekaran, M.; Shiang, W.; Roof, G. R. WO97/05184. Chem. Abstr. 1997, 126, 225700y.

(40) Khan, A. L. T.; Sreearunothai, P.; Herz, L. M.; Banach, M. J.; Köhler, A. Phys. Rev. B 2004, 69, 085201.

(41) Chen, S. H.; Su, A. C.; Su, C. H.; Chen, S. A. J. Phys. Chem. B 2006, 110, 4007.

(42) Ryu, G.; Xia, R.; Bradley, D. D. C. J. Phys.: Condens. Matter 2007, 19, 056205. 